\section{Atlas over hemoglobinvarianter}

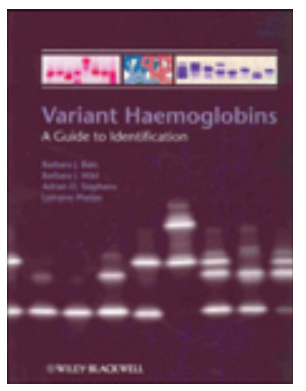

\author{
Barbara J. Bain, Barbara J. Wild,
}

Adrian D. Stephens et al.

\section{Variant haemoglobins}

A guide to identification. $260 \mathrm{~s}$, tab, ill.

Oxford: Wiley-Blackwell, 2010. Pris GBP 90

ISBN 978-1-4051-6715-4

Forfatterene arbeider ved noen av de største britiske sykehus som diagnostiserer og behandler hemoglobinopatier. De tar for seg varianter av hemoglobin som i mange tilfeller kan gi anemisykdommer som talassemi og sigdcelleanemi. Dette har tradisjonelt vært sjeldne sykdommer i Norge, men med endret demografi har medisinske laboratorier og indremedisinske poliklinikker et økende antall henvendelser som skyldes sykdommer knyttet til hemoglobin. Den genetiske kodingen av hemoglobin er komplisert, og fungerer som en mal for hvordan andre gener er regulert. Både mutasjoner og endret regulering av ulike globingener kan gi sykdom, og læren om hemoglobinopatier er derfor modell for mange enkle og mer kompliserte genetiske sykdommer. Hemoglobinvarianter er i stor grad geografisk fordelt, og forteller sin egen historie om store og små folkeforflytninger. I noen regioner, slik som Kypros, har testing av hemoglobinvarianter fått stor betydning for hvem man bør stifte familie med, og testing av nyfødte er aktuelt i flere vestlige land.

Boken er et oppslagsverk og målgruppen er først og fremst leger og laboratoriepersonell som arbeider med diagnostikk av hemoglobinopatier. Over halvparten av innholdet består av plansjer som viser de enkelte hemoglobinvariantene med minst tre ulike måleteknikker.

Det første av de fire kapitlene starter med globingenene og oppbygging av hemoglobinet. Deretter presenteres analysemetoder og klinisk viktige hemogobinvarianter og talassemi. De siste 171 sidene er et atlas som viser kromatogrammer av ulike hemoglobinvarianter. Språket er klart og teksten lett å lese. Layout er gjennomført med gode illustrasjoner. Grafene og kurvene som presenteres er ofte enkelt utført, og gjerne fra de enkelte måleinstrumentene eller regneark. Dette vil nok gi boken en klar tidskoloritt. Teknisk gode kromatogrammer av globinproteiner presenteres i fotoer med meget god kvalitet. I innholdsfortegnelsen listes oversiktelig opp varianter av hemoglobin, og det vises til kromatografibilder og HPLC-retensjonstid for den enkelte type hemoglobin. Boken er innbundet og med glanset papir, og vil trolig tåle lang tids daglig bruk.

Det er funnet et svimlende stort antall globingenmutasjoner som kan gi mer enn 950 varianter av hemoglobin, mer enn 100 alfatalassemimutasjoner og mer enn 200 betatalassemimutasjoner. Men det er kun et lite antall varianter av hemoglobin som gir sykdom, og det er laboratoriediagnostikk av disse forfatterne setter søkelyset på.

To viktige prinsipper blir presentert. Det første er at minst to ulike laboratoriemetoder bør brukes for å bestemme hemoglobinvariantenes natur. Dernest at diagnostikk av varianthemoglobiner må settes i en klinisk sammenheng. Familiehistorie, etnisk bakgrunn, hematologiske målinger og blodutstryk er nødvendig for å stille diagnosen og sette den inn i en meningsfull sammenheng.

De ulike proteinbaserte diagnostikkmetodene som brukes for å undersøke hemoglobin blir omtalt, og det blir pekt på sekvensering av globingener som en viktig del av utredningen. Det som er helt nytt er bruk av massespektrometri for å bestemme mutasjoner i globingener. Dette er en teknikk hvor hemoglobinet klippes opp i små peptider i reagensrøret, og hvor peptidmassen bestemmes med stor nøyaktighet basert på peptidets «flygetid» i et måleinstrument med vakuum og høytvolt spenningsfelt. Proteinmåling med massespektrometer har så vidt entret metoderepertoaret i klinisk biokjemi, og vi vil trolig få glede av denne metoden ved andre indremedisinske tilstander, som proteinavleiringssykdommer og paraproteinemier.

Boken anbefales som oppslagsverk for laboratorieleger. Leger som vil sette seg inn i den spennende verdenen av hemoglobinsykdommer bør starte med en enklere innføringsbok i blodsykdommer (1). De fleste kliniske laboratorier ved universitetsklinikker i Norge tilbyr laboratorieutredning av hemoglobinopatier. Alle leger som arbeider med anemiutredning, bør orientere seg om hvor man kan søke råd og sende blodprøver for å utrede mulige hemoglobinopatier.

\section{Bjørn Tore Gjertsen}

Seksjon for blodsykdommer

Medisinsk avdeling

Haukeland universitetssykehus

Litteratur

1. Hoffbrand AV, Moss PAH, red. Essential haematology. 6. utg. Oxford: Wiley Blackwell, 2006

\section{Grunnleggende om akutt luftveishåndtering}

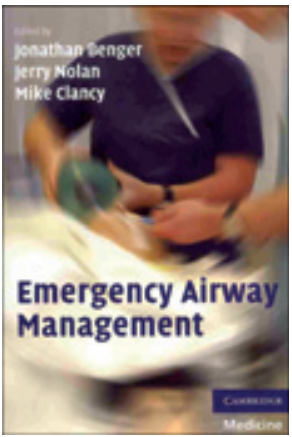

Jonathan Benger, Jerry Nolan,

Mike Clancy, red.

Emergency airway management

175 s, tab, ill. Cambridge: Cambridge

University Press, 2009. Pris GBP 33

ISBN 978-0-521-72729-7

Ufri luftvei er en trussel som mange akuttmedisinske pasienter er utsatt for, og dessverre er det fortsatt slik at noen ender opp med permanent hjerneskade grunnet problemer med å holde åpne luftveier og adekvat ventilasjon. Derfor er kunnskaper og ferdigheter i luftveishåndtering så basalt for alt helsepersonell, og leger i særdeleshet. Det legges stor vekt på at avansert luftveishåndtering ikke er et mål i seg selv, men å sikre tilstrekkelig oksygenering og utlufting av kardondioksid. Det er derfor de grunnleggende og enkle teknikker er så viktig å beherske for den enkelte lege. Og for å være i stand til dette må man øve, øve og atter øve!

Denne boken er offisiell kurslitteratur til et nytt britisk kurs i akutt luftveishåndtering for leger i alle deler av akuttmedisinen. Redaktørene og de 17 andre forfatterne er da også toneangivende kolleger innen britisk akuttmedisin, anestesiologi og intensivmedisin. Boken er således representativ for dagens gjeldende krav til og syn på dette feltet. De 14 kapitlene tar for seg de mange sider ved temaet, og er godt oppdatert med ferske referanser. Den har i god britisk tradisjon mange tabeller, illustrasjoner, fotoer, fornuftige og praktiske anbefalinger. Såkalte supraglottiske hjelpemidler, altså tiltak der man ikke skal intubere pasientens nedre luftveier, er også viet nødvendig oppmerksomhet.

Teksten er ganske lettlest, selv om jeg kunne ha tenkt meg litt større skrift. Det lille formatet til tross, rommer boken mye nyttig informasjon og praktiske tips. Papirkvaliteten er god og det samme er illustrasjonene. Jeg anbefaler den som en passende morgengave til ferske leger i spesialisering i anestesiologi, men den passer absolutt også for legevaktleger og ambulansepersonell som vil lære grunnleggende luftveishåndtering. Det burde de gjøre.

\section{Guttorm Brattebø}

Akuttmedisinsk seksjon

Kirurgisk Serviceklinikk

Haukeland universitetssykehus 